\title{
New Pathways into Creative Work?
}

\author{
Stephanie Taylor and Susan Luckman
}

\section{INTRODUCTION}

Two decades into the twenty-first century, there appear to be multiple entry points into the cultural and creative industries. As the first chapter of this collection indicated, aspirants to a creative career may undertake vocational training or higher education courses or, more auto-didactically, attempt to monetise their personal enthusiasms and amateur activities. Yet for most, there is no clear way ahead beyond the first few steps. The very notion of a pathway implies a visible route, but research has repeatedly noted that this does not exist for most contemporary creative workers. This concluding chapter of the collection considers classic accounts of the pathway into working life and their differences from those in creative work and contemporary work more generally. This chapter discusses the 'false promise' implied in some accounts of creative work. Finally, it considers

\author{
S. Taylor $(\bowtie)$ \\ Faculty of Social Sciences, The Open University, Milton Keynes, UK \\ e-mail: stephanie.taylor@open.ac.uk \\ S. Luckman \\ UniSA Creative, University of South Australia, Adelaide, SA, Australia \\ e-mail: susan.luckman@unisa.edu.au \\ (C) The Author(s) 2020 \\ S. Taylor, S. Luckman (eds.), Pathways into Creative \\ Working Lives, Creative Working Lives, \\ https://doi.org/10.1007/978-3-030-38246-9_15
}


the viewpoint of the workers themselves and the reasons that they may continue to seek entry to a creative working life.

\section{The Conventional Pathway into Working Life}

The image of a pathway implies a transition that is both knowable and known. One classic account of the pathway from education into work is Paul Willis's ethnographic study of the experience of English workingclass 'lads'. In Learning to labour (1977), Willis argued that school education functioned as preparation for working life, not only for successful middle-class students but also for working-class kids who had failed academically. He suggested that boys or young men who resisted school discipline and study were engaging in a 'counter-school' culture that was an appropriate preparation for their future lives. Their negative reaction to school made them receptive to the manual work that would be available to them. This would be physically demanding, impersonal and conventionally masculine labour, in contrast to 'feminised' study. Their future employment would be well paid and secure, even if the work itself was largely unrewarding, offering little mental stimulation or satisfaction. Willis predicted that for these young men, after the initial novelty had passed, the hope attached to having a job would run out early. However, they would then endure the work because it was the necessary underpinning for the places they had already taken up in society through conventional relationships of early marriage and parenthood. Willis therefore offered a totalising, if pessimistic, account of pathways into work that perpetuated existing social divisions and a larger order, integrating schooling, employment and social class.

Willis's young men followed a coherent work-life pathway, although it was one that ultimately gave them limited satisfaction. The working life Willis anticipated for his 'lads' corresponded broadly to an ideal that, Ursula Huws suggests, became established in the mid- to late twentieth century as a 'legitimate aspiration' (Huws 2013, p. 2) for Western workers. The ideal was that 'employers should provide continuous, contractually formalised employment, offering regular holidays, sick pay, pensions and prospects of advancement' (Huws 2013, p. 2). However, Huws notes that the possibility of such positive terms of employment was already being eroded from at least the 1970s. In the UK and many similar economies, the international oil crisis, technological innovations and the global relocation of manufacturing all threatened the security of many workers. 
Moreover, the ideal terms of employment had never corresponded to a 'universal reality'. As Angela McRobbie (2016) points out, work has always been precarious for much of the working class, especially women and migrant workers. Yet, the ideal is relevant for this collection because it has persisted in the hopes and dreams of successive generations. Despite academic and media accounts of increasing precarity, there is still an expectation that aspiring workers will find a pathway to work on these more secure terms. This is the expectation that is invoked in university marketing, for instance, in the lists of industries that an institution's alumni have entered. There is a strong implication that students will transition smoothly from graduation into a career. This is also the expectation that the creative sector has been widely criticised for betraying, for example, when academics have noted its failure to provide stable employment, financial security or a predictable 'age-stage' career trajectory for most of its workers (see, for example, Gill and Pratt 2008).

\section{The Distinctiveness of Creative Work Experience}

Aspirants to contemporary creative work have no clear pathway to follow, and this is not the only respect in which their experience differs from that of the 'lads' Willis studied. Indeed, contemporary creative work might appear to the complete converse of the 'labour' he described. Unlike many mid-twentieth-century jobs, creative work tends to be badly paid, and employment is on precarious terms. Creative work entails intellectual rather than physical effort. It requires personal involvement and flexible self-presentation, sometimes in direct conflict with conventional masculinities (Morgan and Nelligan 2015). Creative work is individualised, without either the support or constraints of a collective workplace culture. The long hours, the pressure to be flexible and mobile, and the high level of personal investment all sit uneasily with the claims of partners and dependents (Conor et al. 2015; Taylor and Littleton 2012); creative work therefore inhibits integration into conventional social relationships. All these challenges might prompt us to revisit Willis's opening words: 'The difficult thing to explain about how middle-class kids get middle-class jobs is why others let them. The difficult thing to explain about how workingclass kids get working-class jobs is why they let themselves' (Willis 1977, p. 1). Now we could ask why people from comfortably middle-class backgrounds 'let themselves' aspire to creative careers. Moreover, as Chap. I indicated, opportunities in the creative industries vary according to not 
only class but also race, gender, ethnicity, age and levels of disability so that even middle-class aspirants may not be let in.

Willis's account rested, first, on established connections between work and class, and second, on his approach to class as an unproblematised category that was easily recognisable, by both those who belonged to it and their academic observers. His working-class categorisation attached not only to people but to occupations, schools and whole towns. In the twenty-first century, following the expansion of the service sector, the 2008 downturn and its continuing effects, and the global relocation of heavy industries and manufacturing, class barriers certainly persist but the divisions and intersections are more complex. There are also great changes in the experience of successive generations. For example, this is a period in which increasing numbers of young people are attending university so that some of the people who enter the cultural and creative industries as graduates may have been the first in their families to receive tertiary education. Arguably, they are part of an upward transition, at least in their own eyes, but at the same time, middle-class entrants to the sector may be losing the employment security that their parents had expected. The categories of privilege and disadvantage are therefore blurring in both directions. Angela McRobbie (2016) notes that in many creative jobs, 'there is an inflation of status at the same time as there is a deflation of earning power' (p. 42). At the margins of the cultural and creative industries, there is also an 'upgrading of the service sector' (p. 43), for example, in barista jobs. Aspiring entrants to creative work therefore face uncertainty, not only in the terms of their future employment but also around the meanings attached to their work, and the social positions and identities it provides.

Additionally and most pertinently for this collection, the pathways into creative work differ greatly from those associated with the earlier ideal of work and employment, discussed in the previous section. As Chap. 1 indicated, becoming a creative worker will seldom be reducible to the kind of single, once-for-all transition described by Willis. Instead, preparation for work is likely to involve an extended up-and-down process of learning and further learning, personal rebranding, the transferring of skills and their continuous upgrading to keep up with technological change.

In all these respects, creative work contrasts with the earlier ideal, perhaps even constituting a response to and escape from the experience of workers like Willis's lads. Yet the contrast can also be overstated. The earlier ideal of work and employment set out by Huws (2013) of course referred mainly to men. It assumed the relegation of women to a 
supporting domestic role. Despite its feminised and apparently politically progressive aspects (Gill 2014; Taylor 2011), creative work perpetuates gendered privilege. There are also barriers to the entry of black and minority ethnic people into the creative sector, even if the racism they encounter may (mostly) be less obvious and less overtly brutal than that described by Willis (Allen, this collection; Patel, this collection). In addition, as many writers have noted, creative work involves affective labour (Ekinsmyth 2014; McRobbie 2011; Negri 2008; Ouellette and Wilson 2011) in order to present desired identities and to cultivate the 'right' kind of self in an environment where 'life is a pitch' (Gill 2010). There is also pressure to deny difficulties; Gill (2014) notes the need for creative workers to be continuously positive. All these forms of performance may require a denial of self similar to that described by Willis, despite the much celebrated association of creativity with self-actualisation and personal fulfilment.

\section{The Contemporary Work Experience}

Comparison of the cultural and creative industries with the earlier experience and ideal raises a further question: how far are the difficulties faced by creative workers part of a wider social phenomenon? A number of writers would associate the changes in work with a more general transition (Sennett 1998), for example, from Fordism to post-Fordism (Adkins and Dever 2016). A 2019 collection edited by Enzo Colombo and Paola Rebughini (2019a) presents European research on the experience of young people today. In their introduction, Colombo and Rebughini (2019b) argue that all young people must now be flexible enough to contend with 'complexity and uncertainty'. In other words, the point is made again that there is no longer a mapped-out pathway to follow. Rather, each young person entering work must construct an individual way forward: 'Navigating the present, with its multiplicity, its instability and the uncertainty of seizing the right moment, means being able to translate experiences and competences from one situation to another' (p. 11). This is now a general requirement, although the skills and resources required for the navigation are not equally distributed. Like Willis, Colombo and Rebughini note how experience differs according to family and class. For example, those who have more social and economic resources will be able to manage longer 'transition phases' between the kinds of work that they want.

Like Willis, Colombo and Rebughini (2019b) are discussing general pathways into work, without specific reference to creative work. Some of 
the noted challenges of creative work are presented as imperatives for all contemporary workers. For example, much has been made of the 'personal' nature of creative work (e.g. Taylor and Littleton 2012). However, Colombo and Rebughini suggest that an 'over-investment in personal capacities' is simply a way of reframing contemporary difficulties to make them appear more manageable. Similarly, 'self-presentation' (Conor et al. 2015 , p. 13) has been claimed as a requirement for creative workers (Gandini and Pais, this collection), but Colombo and Rebughini (discussing Theodoridis et al. 2019) suggest that in the absence of other possibilities for young people, 'action ... can be reduced to the maintenance of a self-image, often virtual and disconnected from real experience, which conforms to social expectations' (p. 13, emphasis added). A parallel argument can be made about creativity itself. Colombo and Rebughini suggest that ' $\mathrm{t}]$ he capacity of improvisation and adaptation becomes a new form of agency' for dealing with the challenges of navigation (p. 10). In other words, 'navigating the present' requires all young people to be creative. In short, Colombo and Rebughini's account seems to indicate that many of the supposed difficulties of creative work are increasingly more general features of contemporary life: creative work does not have a special significance or status, and the experience of creative workers is inseparable from that of other contemporary workers. The contrary view is that creative work must be considered as a separate category precisely because of the idea of creativity and the pathway that it implies.

\section{The Pathway of (False) Promise}

A number of writers on contemporary creative work have proposed that the promise of creativity has a particular function in the workings of contemporary societies, economies and labour markets. This section discusses examples of such accounts from Australia, the UK and Germany.

In research from Australia that specifically focuses on creative workers, George Morgan and Pariece Nelligan (2018) explain creative work as part of the contemporary phase of capitalism. They suggest that the false promise of creativity motivates young people to enter careers in which they have few prospects. There are too many aspirants for the work that is available, so most will have to compromise and accept the precarious working life of the gig economy, doing unrewarding small jobs that are often 'talked up'. (Morgan and Nelligan [2018] cite the ludicrous example of an advertisement calling for a job applicant who is 'passionate' about selling pet 
accessories: p. viii.) Morgan and Nelligan also propose the concept of 'feral enterprise', meaning 'an acceptable version of capitalism that purports to be faithful to the resistant, craft, bohemian and/or iconoclastic values of creativity' (p. 123). Their argument is that such supposedly creative businesses that do succeed are likely to be following conventionally brutal capitalist practices behind a benign creative shopfront. As the title of their book indicates, Morgan and Nelligan see the promise of creativity as a 'hoax', but one that is functional for 'modern capitalism' (p. 14).

There are parallels between Morgan and Nelligan's (2018) arguments and Angela McRobbie's (2016) widely cited account of the 'new creative economy'. Following Foucault, McRobbie proposes the term 'creativity dispositif' to refer to 'a self-monitoring, self-regulating mechanism' (p. 38) in which a romantic notion of creativity persuades young people to accept insecurity. McRobbie suggests that '[w] hat starts as an inner desire for rewarding work is re-translated into a set of techniques for conducting oneself in the uncertain world of creative labour' (p. 37). She is particularly interested in young people who have followed a higher education pathway (see Chap. 1). She suggests that young workers, especially young women, discipline themselves to manage the difficulties of creative work cheerfully and enthusiastically, accepting low earnings (often lower than their parents made) and supporting themselves by taking relatively mundane jobs, such as shop assistant and barista, which have been re-labelled in terms of 'enhanced and upgraded creative values' (p. 44).

These two accounts by Morgan and Nelligan (2018) and by McRobbie (2016) set out a particular aspirational and affective pathway into creative work. Would-be creative workers begin with high expectations but achieve only low-status poorly paid work. They seek to reconcile themselves to this situation, with varying degrees of success, accepting the difficulties as part of a larger new normal of working life. Thus, despite their early experiences, they persist. This is an engagement in 'hope labour' (Kuehn and Corrigan 2013), following the anticipation of creative rewards that may never be attained. There is an odd parallel here to the account of Willis's lads, who would also become locked into largely unsatisfying, if better paid, work, although in their case by their responsibilities to others rather than their own creative aspiration.

A similar but somewhat more positive account is presented by Andreas Reckwitz (2012/2017). Unlike Morgan and Nelligan or McRobbie, Reckwitz does not present the aspiration to creativity as one that will almost inevitably be disappointed. Like McRobbie, he draws on Foucault 
and discusses the creative dispositif, but from a broadly Weberian theoretical tradition. Reckwitz suggests that the rise of 'organised modernity' (p. 203) in the late nineteenth and early twentieth centuries produced a rationalised society: 'The Fordist economy, with its mass production, its hierarchical functionalist organization and standardised consumption, the psychology of social control, and the planning regime of the functional city are all constituents of organized modernity' (p. 203). What was lacking in this context was emotion and affect. Workers had no motivation to participate in work. Reckwitz $(2012 / 2017)$ argues that the more recent aspiration for the aesthetic and the rise of the creativity dispositif are responses to this deficiency. Both centre on an image of the artist as 'the creative subject' (p. 206). The image has been further promoted by psychology (see also Taylor 2019) and a mass media celebrity culture. As a consequence, creativity has become highly valued: 'It is not the disciplined but, rather, the expressive individual who becomes the popular cultural ideal' (Reckwitz 2012/2017, p. 206). The ideal is functional for a larger social order because of the motivation it provides for workers.

The fourth account to be discussed in this section is from Scott Brook (2016). His interest is in a rationale for tertiary creative education that rests on its supposed relevance to the wider economy. Brook looks back to the work of the Australian cultural studies theorist Ian Hunter, who utilised Foucault's principles of governmentality in his analysis of the history of education. Hunter proposed that in the early twentieth century, literary education was seen to provide good moral and ethical training because it promoted 'a range of intimate techniques for ethical self-inspection and moral correction' ( $\mathrm{p}$. 33). The classroom teacher would be a model of the desired 'type', demonstrating 'good taste and rhetorical facility' (p. 33). These ideas derived from a celebration of the artist as a person who enjoyed 'psychological health and well-being' because of his/her 'sensitivity to experience' (p. 33). (Taylor [2019] discusses other twentieth-century celebrations of the artist as a desirable exemplar.)

Brook's (2016) argument is that in the late twentieth century the artist again came to be seen as a model and exemplar, but this time for economic practices appropriate for the general working population. The artistic type was considered to be especially suited to managing the uncertainties of late twentieth-century employment because of a tendency to selfexploitation and a readiness to take risks and blur the boundaries between work and leisure. This fitted with a perceived new requirement for workers to 'adopt a more creative approach to their own employability' (p. 35). 
The parallels between the artist and the entrepreneur have been widely noted (e.g. Taylor 2019). Brook's (2016) additional argument is that these parallels were taken up in higher education, enabling creative education to be reinterpreted as enterprise education, with reference to 'employability and enterprise skills' (p. 34). A different career pathway came to be defined and celebrated. In contrast to the linear pathway of conventional employment, Brook defines this 'protean career' as 'an emergent form characterised by mobile and intermittent forms of self-employment, multiple job-holding and short-term contract work, and which is motivated by subjective perceptions of meaningful work' (p. 35).

Writing in the Australian context, Brook (2016) explicitly links the creative industries project within higher education to the expansion in student places as part of a policy of university 'massification' (p. 27). The greater numbers of people attending and graduating from university with a degree produce 'academic inflation' (Brook 2016, p. 32). In such an environment, having a creative degree is no longer a mark of distinction or a unique selling point in the crowded creative labour market. However, Brook (2016) argues that a reinterpretation of creative education in Hunterian terms has been functional for universities themselves, particularly in Australia. It resolves a problem that faced Australian universities in the late twentieth century, of students' preference for arts and humanities subjects, which at the time were considered to have limited vocational or, on the larger scale, national economic value. The reinterpretation also accommodates the supposed over-supply of creative graduates because they can be argued to benefit the wider economy as 'embedded creatives' who work in different sectors. The supposed relevance of creative education to all kinds of contemporary work removes the pressure on universities to demonstrate that creative graduates gain employment in the cultural and creative industries.

Arguably, the reinterpretation is also functional for creative graduates themselves because of the positive self-identification that it offers. The graduates can take pride in themselves for their personal qualities as creative people, and they can also be reconciled to work outside the cultural and creative industries, applying their personal creativity to activities that would not conventionally be seen as creative work. Terry Flew (2019) presents a similar argument, suggesting that the artist has been 'reversioned' as what Michel Foucault (2008, p. 226) termed an 'entrepreneur of the self' (Flew 2019, p. 169). Brook's account therefore offers a different explanation of why people may continue to seek pathways into creative 
work. It suggests that the reinterpretation of the creative type has channelled, if not completely tamed, the counter-cultural or oppositional tendencies of the artist. The new ideal functions to condition graduates for more prosaic and difficult future careers in much the same way that Willis's 'counter-school' culture did for working-class lads.

The accounts discussed in this section invoke different versions of the creative worker. Reckwitz's $(2012 / 2017)$ determined searcher for affective rewards perhaps resembles the aware young person described by Colombo and Rebughini (2019b), consciously mobilising all available resources in order to navigate precarious work opportunities as effectively as possible. In contrast, the young person invoked by McRobbie (2011, 2016) and Morgan and Nelligan (2018) is lured by false promises to serve the current needs of capitalism or at least tolerate its difficulties, as much a victim as the passive, even blinded figure of Willis's (1977) lad who had been socialised into compliance. Brook's creative graduate is also reconciled to a difficult working life, but with the (partial) compensation of a strong personal conviction of their own self-worth as a creative person. The common features of the accounts are, first, the focus on the promise of creativity as an inducement that functions to constitute a contemporary worker subject, and second, the suggestion of continuing tensions between the expectations attached to creative work and its contemporary realities. The concluding section of this chapter also considers the viewpoint of the worker, but suggests that it may prompt a different interpretation of possibilities and pathways.

\section{A Worker's View of the Pathway}

Despite the very real problems that have been noted in this chapter and in the collection more generally, some creative workers do discover a pathway to a positive situation. A few will achieve the 'big break' of recognition and financial success. Others may give up the hope of creative work, perhaps entering a completely different kind of occupation that still offers the certainty and forward projection described by Willis (1977) and Huws (2013). Yet, others may knit together their work and life circumstances into a combination that has no neat description but functions for them personally, enabling them to achieve sufficient income alongside the pleasure of creative satisfaction. This may involve a compromise of their 
original ambitions, in the kind of "shovel work"1 that enables them to earn in a related but less creative activity, like the managers of the co-working sites discussed by Morgan (this collection). The creative practitioners who become teachers are probably another example of the compromise. And the workers who accept the interpretation of cultural education that Brook (2016) (critically) describes may reinterpret their skills as functional for work that has no conventional connection to the creative industries.

For those who are not in the last category, and especially for new aspirants, there remains the question of why the appeal of creativity and creative work apparently persists in the face of several decades of critical debate and evidence concerning the problems of creative working lives. An answer must consider the workers' own viewpoint, and this may give rise to a different logic from that presented in the previous section. Taylor (2019) argues that too little attention has been paid to how creative workers themselves understand creativity. She found that creative practitioners had a different conceptualisation from that of the academics and policymakers who have contributed to its contemporary celebration. This 'practitioner concept' of creativity is 'not coherent or unified' (p. 466), and it is 'not identical to any one of the academic conceptualisations, although there are some parallel assumptions' (p. 453). To conclude this chapter, we will consider two of the implications of the practitioner concept for creative pathways.

The first aspect of the practitioner concept to be noted is that it emphasises transcendence (Taylor and Paludan 2019) and an escape from the mundanities of so-called ordinary life. This would suggest that some creative workers are not searching for a pathway to the kind of conventional work success that is marked by external recognition, promotion or increased earnings (Luckman 2018). Instead, the attraction of creativity may be as an escape from ordinary life and ordinary work. For this reason, too, it is important to note that not all creative entrants are young; they include many who find themselves in an economic and/or family position where they are finally free to pursue a creative dream previously unavailable to them (Luckman and Andrew 2020).

Transcendence derives in part from the associations of creativity with the elite arts. Mark Banks (2017) has criticised accounts of the creative economy that reduce creative objects and outputs to their sociological

\footnotetext{
${ }^{1}$ As noted in Chap. 1 , this is a term derived from the often-quoted maxim that the most reliable way to make money in a gold rush is to sell shovels.
} 
significance, calling for acknowledgement of the kind of creative and aesthetic value (Born 2010) that is evaluated by art historians, among others. Some practitioners may indeed aspire to creative work that is 'good' in these aesthetic terms and apply similar criteria to their own practice and outputs (e.g. see Hesmondhalgh and Baker 2011). Others may adopt different markers of value, such as the supposed therapeutic utility of a creative practice or outputs (Taylor and Paludan 2019). In either case, the self-defined markers potentially allow the workers to define achievement and fulfilment in different terms to those which are conventionally applied to work and employment. For example, workers may formulate an alternative interpretation of a progressive pathway as a developing and maturing practice. Another kind of pathway may be defined by political and ethical concerns (Banks 2007), such as a desire to live a 'greener' life, resisting growth and reducing climate impacts, or to operate in a more communityoriented social enterprise or intentional economy mode (Gibson-Graham 2006). In short, the workers may choose to define their own pathways, escaping from both conventional and contemporary evaluations of appropriate achievement and success.

The second relevant aspect of the practitioner concept derives from the linking of creativity to the self. This personal identification, noted by many researchers (e.g. Taylor and Littleton 2012), makes creativity the 'generative principle' (Bourdieu 1996, p. 187) of a life narrative. The self endures, so creative identification becomes a source of continuity through a stopstart pathway of uncertain employment and changing life circumstances, substituting for the continuity that was previously given by Fordist or modernist employment and careers. Moreover, somewhat paradoxically, this alternative continuity also accommodates episodic manifestations. In a precarious working life, the creative self emerges and retreats. Obviously, in times of drudge work, such as a 'day job' accepted just to make ends meet (Morgan and Nelligan 2018, p. 13), the creative self is not being mobilised, but neither is it erased or invalidated. Understood in this way, a creative pathway can be detached from the linear narrative of biological ageing which marked the experience of Willis's lads. A creative career does not necessarily start at a specified age and life point, like school leaving, and then proceed in step with the passing of time and conventional life stages. Of course, this detachment of the creative pathway from the biological narrative gives rise to one of the noted problems encountered by creative workers, that their working lives do not readily accommodate the taking up of responsibilities associated with traditional family life. But the 
positive corollary is that the creative pathway may be joined or resumed at many life points. The creative self remains available, as in the situation of people who have spent many years looking after children or doing some other kind of dutiful work before reclaiming their creativity in a change of life and work arrangements (Luckman and Andrew 2020; Taylor and Paludan 2019). The pathway is no longer linked to age or life circumstances: its possibilities continue, undiminished.

\section{REFERENCES}

Adkins, L., \& Dever, M. (Eds.). (2016). The post-Fordist sexual contract: Working and living in contingency. Basingstoke: Palgrave Macmillan.

Banks, M. (2007). The politics of cultural work. Basingstoke: Palgrave Macmillan.

Banks, M. (2017). Creative justice: Cultural industries, work and inequality. London: Rowan and Littlefield.

Born, G. (2010). The social and the aesthetic: For a post-Bourdieuian theory of cultural production. Cultural Sociology, 4, 171-208.

Bourdieu, P. (1996). Rules of art: Genesis and structure of a literary field. Cambridge: Polity.

Brook, S. (2016). The exemplary economy: A Hunterian reading of the creative industries as educative project. International Journal of Cultural Policy, $22,27-40$.

Colombo, E., \& Rebughini, P. (2019a). Youth and the politics of the present: Coping with complexity and ambivalence. London and New York: Routledge.

Colombo, E., \& Rebughini, P. (2019b). A complex uncertainty: Young people and the riddle of the present. In E. Colombo \& P. Rebughini (Eds.), Youth and the politics of the present: Coping with complexity and ambivalence (pp. 1-16). London and New York: Routledge.

Conor, B., Gill, R., \& Taylor, S. (2015). Gender and creative labour. In B. Conor, R. Gill, \& S. Taylor (Eds.), Gender and creative labour (pp. 1-22). Chichester: Wiley Blackwell and The Sociological Review.

Ekinsmyth, C. (2014). Mothers' business, work/life and the politics of 'mumpreneurship'. Gender, Place and Culture, 21, 1230-1248.

Flew, T. (2019). From policy to curriculum: Drivers of the growth in creative industries courses in the UK and Australia. Creative Industries Journal, $12,167-184$.

Foucault, M. (2008). The Birth of Biopolitics: Lectures at the College of France 1978-9. Basingstoke: Palgrave Macmillan.

Gibson-Graham, J. K. (2006). A postcapitalist politics. Minneapolis, MN: University of Minnesota Press. 
Gill, R. (2010). Life is a pitch: Managing the self in new media work. In M. Deuze (Ed.), Managing media work (pp. 249-262). London: Sage.

Gill, R. (2014). Unspeakable inequalities: Post feminism, entrepreneurial subjectivity, and the repudiation of sexism among cultural workers. Social Politics: International Studies in Gender, State and Society, 21(4), 509-528.

Gill, R., \& Pratt, A. (2008). In the social factory? Immaterial labour, precariousness and cultural work. Theory, Culture and Society, 25, 1-30.

Hesmondhalgh, D., \& Baker, S. (2011). Creative labour: Media work in three cultural industries. London and New York: Routledge.

Huws, U. (2013). Working online, living offline: Labour in the internet age. Work, Organisation, Labour and Globalisation, 7(1), 1-11.

Kuehn, K., \& Corrigan, T. (2013). Hope labor: The role of employment prospects in online social production. The Political Economy of Communication, 1, 9-25.

Luckman, S. (2018). Craft entrepreneurialism and sustainable scale: The persistence and evolution of creative challenges to capitalist growth. Cultural Trends, $27(5), 313-326$.

Luckman, S., \& Andrew, J. (2020). Craftspeople and designer makers in the contemporary creative economy. Cham, Switzerland: Palgrave Macmillan.

McRobbie, A. (2011). Reflections on feminism, immaterial labour and the postFordist regime. New Formations, 70, 60-76.

McRobbie, A. (2016). Be creative: Making a living in the new culture industries. Cambridge and Malden: Polity.

Morgan, G., \& Nelligan, P. (2015). Labile labour-Gender, flexibility and creative work. In B. Conor, R. Gill, \& S. Taylor (Eds.), Gender and creative labour (pp. 66-83). Chichester: John Wiley \& Sons.

Morgan, G., \& Nelligan, P. (2018). The creativity hoax: Precarious work in and the gig economy. New York: Anthem Press.

Negri, A. (2008). Empire and beyond. Cambridge and Malden, MA: Polity.

Ouellette, L., \& Wilson, J. (2011). Women's work: Affective labour and convergence culture. Cultural Studies, 25, 548-565.

Reckwitz, A. (2012/2017). The invention of creativity: Modern society and the culture of the new (S. Black, Trans). Cambridge: Polity Press. (First published in German as Der Erfindung der Kreativität: Zum Process Gesellschaftlicher Ästhetisierung. Berlin: Suhrkamp Verlag.)

Sennett, R. (1998). The corrosion of character. London and New York: W.W. Norton.

Taylor, S. (2011). Negotiating oppositions and uncertainties: Gendered conflicts in creative identity work. Feminism \& Psychology, 21(3), 354-371.

Taylor, S. (2019). A participant concept of contemporary creativity. Social Psychology Quarterly, 82(4), 453-472.

Taylor, S., \& Littleton, K. (2012). Contemporary identities of creativity and creative work. Surrey: Ashgate Farnham. 
Taylor, S., \& Paludan, M. (2019). Transcending utility? The gendered conflicts of a contemporary creative identification. Feminism \& Psychology, 30(1): 63-79.

Theodoridis, K., Miles, S., \& Albertson, K. (2019). Negotiating reality through the prosumption of the 'unreal' self: Young people's identities in an age of economic precarity. In E. Colombo \& P. Rebughini (Eds.), Youth and the politics of the present: Coping with complexity and ambivalence (pp. 32-43). London and New York: Routledge.

Willis, P. (1977). Learning to labour: How working class kids get working class jobs. Abingdon and New York: Routledge.

Open Access This chapter is licensed under the terms of the Creative Commons Attribution 4.0 International License (http://creativecommons.org/licenses/ by $/ 4.0 /)$, which permits use, sharing, adaptation, distribution and reproduction in any medium or format, as long as you give appropriate credit to the original author(s) and the source, provide a link to the Creative Commons licence and indicate if changes were made.

The images or other third party material in this chapter are included in the chapter's Creative Commons licence, unless indicated otherwise in a credit line to the material. If material is not included in the chapter's Creative Commons licence and your intended use is not permitted by statutory regulation or exceeds the permitted use, you will need to obtain permission directly from the copyright holder.

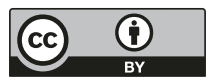

